\title{
An Attempt to Model Factors Affecting the School's Dropout Phenomenon in Yemen
}

\author{
Muhammed Abdul Kareem Al-Mansoob ${ }^{1}$, Muhammed Saleh Abdullah Masood ${ }^{2}$, \\ Abdulhakim Abdurabu Mohammed Al-Abid ${ }^{3}$ \\ ${ }^{1}$ Department of Mathematics, Faculty of Science, Sana'a University, Sana'a, Yemen \\ ${ }^{2}$ Department of Mathematics, Faculty of Education and Language, Amran University, Amran, Yemen \\ ${ }^{3}$ Department of Statistics, Faculty of Commerce, Sana'a University, Sana'a, Yemen
}

\section{Email address:}

darasan.ceo@gmail.com (M. A. K. Al-Mansoob),drmohammedabalan@gmail.com(M. S. A. Masood),

Hakimdeputy@gmail.com (A. A. M. Al-Abid)

\section{To cite this article:}

Muhammed Abdul Kareem Al-Mansoob. Muhammed Saleh Abdullah Masood, Abdulhakim Abdurabu Mohammed Al-Abid. An Attempt to Model Factors Affecting the School's Dropout Phenomenon in Yemen. International Journal of Education, Culture and Society.

Vol. 3, No. 5, 2018, pp. 78-85. doi: 10.11648/j.ijecs.20180305.11

Received: October 15, 2018; Accepted: October 29, 2018; Published: November 26, 2018

\begin{abstract}
Due to many reasons, the dropout problem at the Yemeni schools is escalating tremendously. This study provides an in-depth analysis on school dropouts through analyzing all available and relative raw data that have been obtained in three Yemeni national official surveys: Household Budget Survey (HBS) 2005-2006, Child Labor Survey (CLS) 2010 and HBS 2014. In each survey, a number of dropouts' reasons was investigated and seven of them were found to be common in these three surveys. With attendance status (attended, not attended) as a dependent variable, the binary logistic regression was used to find out statistical significant reasons for school dropouts in Yemen for the two age groups 6-14 and 15-17 years. From each survey, some significant independent variables (reasons) were detected. These significant reasons were divided into six related dimensions namely; poverty, schools' situation, education willingness, orphanhood, sex of the children and residence area. Careful consideration to these dimensions has led to suggest a number of relative recommendations and also a prototype that addresses the dropout problem and its deep roots in Yemen.
\end{abstract}

Keywords: Dropout, HBS, CLS, Logistic Regression, Yemen

\section{Introduction}

The reports of HBS 2005-2006, CLS 2010 and HBS 2014 had mentioned $25.7 \%, 18.2 \%$ and $16.6 \%$ prevalence rates of not attending schools in Yemen respectively [1-3], where the positive progress is clear. However, very recently UNICEF 2018 had estimated 2,000,000 children and adolescents who are in the school ages and out of schools $[4,5]$. Taking into account that the total projected population of children and adolescents aged 6-17 years to be $8,220,000$ [6], it is easy to estimate the new out of school prevalence rate as $24.3 \%$. This relapse is mainly due to the ongoing war that erupted on March 2015 and still storming the whole country that considered as one of the big motives for us to conduct this research. Among the Middle East and North Africa (MENA) countries, Yemen has one of the largest number of children out of school [7, 8]. The National Social Protection Monitoring Survey (NSPMS) reveals that during the 2012/2013 school year, there were around 1.6 million girls and boys aged 6-14 years that were not enrolled in the education system, that is more than a quarter $(27.5 \%)$ of the primary and lower secondary age population is out of school [9]. After three years of brutal war in Yemen, the education system is on the brink of a total collapse as nearly 2 million children-more than a quarter of all school-aged children- are not enrolled during the 2016/2017 school year [4]. One of the major bleak implications of this war is that all public schools' teachers left without salaries for around a year [5]. UNICEF on March 2018, is reporting horrific figures about the schooling situation in Yemen; 2500 schools are out of use, 
$66 \%$ of schools were damaged, $27 \%$ of schools have closed down and $7 \%$ of the left schools are used as shelters for displaced families or for military purposes [5].

Student attendance serves as an effective predictor of future academic achievement as well as of high school graduation [10]. Improving access to schooling surely depends on reducing children drop out. Hunt (2008), arguedin his review- that many factors associated with drop out that lie at the individual, household, school and community level. Moreover, he had come to conclude that drop out is the result of a process rather than a single event, has more than one proximate cause and is fairly irreversible [11]. Yet, identifying the causes of dropping out is extremely difficult. The act of dropping out is influenced by an array of factors related to both the individual student and to the family, school, work-related reasons and community settings in which the student lives [12-14]. If many factors contribute to this phenomenon over a long period of time, it is virtually impossible to demonstrate a causal connection between any single factor and the decision to quit school [14]. Some scholars have viewed dropping out of school as the final stage of a dynamic and cumulative process of disengagement $[15,16]$ or withdrawal from school that is influenced by a variety of proximal and distal factors [17]. Exclusion from the formal educational system has long term implications for the country's social and economic development. At the individual level, literatures showed that low investments in education are strongly associated with higher levels of violence, precarious health, early pregnancy, low productivity and lower earnings [18-20].

Understanding factors that constrain children's school enrollment, is the corner stone for any successful intervention. Various studies have identified a number of factors that constrain children's school enrollment. For example, Filmer (1999) documented a positive significant relationship between school attendance and household level of wealth for 41 developing countries using DHS data [21]. In Egypt, children of poor families tend to be dropped out of school [22] and there was a significant positive association between household level of wealth and child's schooling [23, 24].

The aims of the present research are:

(1) To explore the trend of enrollment of the Yemeni children at school age.

(2) To better understand factors that negatively affecting the Yemeni children's enrollment.

\section{Data Source}

This research intends to use and compare data of three Yemeni national surveys in a period covers a span of 10 years. More precisely, it is intended to use the raw data of HBS 2005-2006, the CLS 2010 and the HBS 2014. The key question in the three surveys was "Is the child is currently attending school". Each survey had compiled, several reasons for not attending. Some reasons were common in the three surveys and others were different. After separating children and adolescents 6-17 years from the raw data of the three surveys, the sample sizes were 10107 of the HBS 2005-2006, 9614 of the CLS 2010 and 21587 of the HBS 2014, among them 2596, 1745 and 3585 children and adolescents were found out-of-school in these three surveys respectively.

\section{Analysis and Results}

The schooling system in Yemen comprises two levels: Basic Education Level that constitutes nine grades for children aged 6-14 and the Secondary Education Level that constitutes three grades for adolescents aged 15-17 inclusive. So, our analysis will be done on these two levels separately wherever suitable.

In this research, our focus will be on children and adolescents who were out-of-school at the surveys time and ignore their schooling history prior to them.

Table 1, is listing seventeen reasons for not enrolling in schools. Six reasons are common in the three surveys; namely "No school", "Family not interested", "Work for someone", "Work for family", "Illness" and "Too young". Too young is the main reason in both CLS 2010 and HBS 2014 for the age group 6-14 years. Family not interested comes as the next important factor specially for female students. Illness of male students in the age group 15-17 of both CLS 2010 and HBS 2014 is another important factor and also questionable. No schools available in the dropouts' areas and also their inability to afford the schooling costs are also major concerns. No female teachers seem to contribute negatively to the process of enrollment. It is very clear that most of the dropouts are of the rural areas in the three surveys. This result is very crucial as it reflects major social discrepancies between urban and rural areas in Yemen. Orphans are less likely to enroll. In HBS 2005-2006; enrolled poor students were less than the non-poor students of HBS 2014.

Table 1. Proportions of out-of-school children and adolescents by reason of not enrolling.

\begin{tabular}{|c|c|c|c|c|c|c|c|c|c|c|c|c|}
\hline \multirow{3}{*}{$\begin{array}{l}\text { Reasons for not being } \\
\text { enrolled in school }\end{array}$} & \multicolumn{4}{|c|}{ HBS 2005-2006 } & \multicolumn{4}{|c|}{ CLS 2010} & \multicolumn{4}{|c|}{ HBS 2014} \\
\hline & \multicolumn{2}{|l|}{ 6-14 } & \multicolumn{2}{|c|}{$15-17$} & \multicolumn{2}{|c|}{$6-14$} & \multicolumn{2}{|c|}{ 15-17 } & \multicolumn{2}{|l|}{$6-14$} & \multicolumn{2}{|c|}{$15-17$} \\
\hline & $\mathbf{F}$ & $\mathbf{M}$ & $\mathbf{F}$ & $\mathbf{M}$ & $\mathbf{F}$ & $\mathbf{M}$ & $\mathbf{F}$ & $\mathbf{M}$ & $\mathbf{F}$ & $\mathbf{M}$ & $\mathbf{F}$ & M \\
\hline No schools & 9.2 & 11.4 & 9.7 & 11.5 & 8.6 & 9.0 & 14.5 & 10.5 & 5.3 & 3.2 & 11.9 & 11.7 \\
\hline Hard to reach & 11.3 & 13.9 & 4.9 & 9.4 & & & & & 3.1 & 2.2 & 8.1 & 6.4 \\
\hline Child not interested & 18.3 & 17.1 & 25.6 & 28.0 & 5.5 & 4.6 & 13.2 & 21.1 & & & & \\
\hline Family not interested & 29.2 & 27.9 & 28.5 & 18.8 & 7.1 & 2.1 & 23.7 & 2.6 & 10.8 & 4.9 & 44.6 & 25.5 \\
\hline Work for someone & 0.1 & 0.0 & 1.3 & 0.3 & 0.1 & 0 & 0 & 0 & 0.1 & 0.3 & 0.4 & 1.1 \\
\hline Work for family & 7.0 & 7.1 & 10.2 & 10.5 & 0.1 & 0.3 & 1.3 & 0 & 1.5 & 0.2 & 3.8 & 0 \\
\hline No teachers & 1.1 & 1.6 & 0.5 & 1.0 & & & & & 1.2 & 1.7 & 0.8 & 4.3 \\
\hline No female teachers & 17.4 & 12.6 & 15.1 & 16.2 & & & & & 3.6 & 0.1 & 11.2 & 1.1 \\
\hline
\end{tabular}




\begin{tabular}{|c|c|c|c|c|c|c|c|c|c|c|c|c|c|}
\hline \multirow{3}{*}{\multicolumn{2}{|c|}{$\begin{array}{l}\text { Reasons for not being } \\
\text { enrolled in school }\end{array}$}} & \multicolumn{4}{|c|}{ HBS 2005-2006 } & \multicolumn{4}{|c|}{ CLS 2010} & \multicolumn{4}{|c|}{ HBS 2014} \\
\hline & & \multicolumn{2}{|l|}{$6-14$} & \multicolumn{2}{|c|}{$15-17$} & \multicolumn{2}{|l|}{ 6-14 } & \multicolumn{2}{|c|}{$15-17$} & \multicolumn{2}{|l|}{$6-14$} & \multicolumn{2}{|c|}{$15-17$} \\
\hline & & $\mathbf{F}$ & M & $\mathbf{F}$ & M & $\mathbf{F}$ & M & $\mathbf{F}$ & M & $\mathbf{F}$ & M & $\mathbf{F}$ & M \\
\hline \multicolumn{2}{|l|}{ Illness } & 0.1 & 0.2 & 0.1 & 0.0 & 3.7 & 4.4 & 5.3 & 39.5 & 3.5 & 4.0 & 4.6 & 26.6 \\
\hline \multicolumn{2}{|c|}{ Pregnancy } & 0.0 & 0.0 & 0.0 & 0.3 & & & & & & & & \\
\hline \multicolumn{2}{|c|}{ Lack of sanitation } & 1.6 & 3.0 & 0.1 & 0.0 & & & & & & & & \\
\hline \multicolumn{2}{|c|}{ Too young } & 18.3 & 17.1 & 25.6 & 28.0 & 63.3 & 72.2 & 0 & 2.6 & 62.4 & 76.5 & & \\
\hline \multicolumn{2}{|c|}{ Education isn't valuable } & & & & & 1.1 & 0.6 & 6.6 & 5.3 & & & & \\
\hline \multicolumn{2}{|c|}{ School isn't safe } & & & & & 1.4 & 0.6 & 2.6 & 2.6 & 0.4 & 0.1 & 0.4 & 1.1 \\
\hline \multicolumn{2}{|c|}{ To help in the household tasks } & & & & & 1.7 & 0 & 10.5 & 0 & & & & \\
\hline \multicolumn{2}{|c|}{ Others reasons } & 4.7 & 5.3 & 4.2 & 3.9 & 0.4 & 0.8 & 2.6 & 0 & 2.2 & 2.2 & 3.1 & 6.4 \\
\hline \multicolumn{2}{|c|}{ Sample size } & 919 & 438 & 857 & 382 & 807 & 724 & 76 & 38 & 1752 & 1479 & 260 & 94 \\
\hline \multirow{2}{*}{ Area } & Urban & 30.6 & 29.2 & 38.8 & 39.1 & 40.1 & 43.0 & 26.3 & 42.9 & 43.3 & 50.6 & 24.9 & 44.2 \\
\hline & Rural & 69.4 & 70.8 & 61.2 & 60.9 & 59.9 & 57.0 & 73.8 & 57.1 & 56.7 & 49.4 & 75.1 & 55.8 \\
\hline \multirow{2}{*}{ Mother } & Living & 80.0 & 66.6 & 76.3 & 59.8 & 99.3 & 99.2 & 92.5 & 97.6 & & & & \\
\hline & Died & 20.0 & 33.4 & 23.7 & 40.2 & 0.7 & 0.8 & 7.5 & 2.4 & & & & \\
\hline \multirow{2}{*}{ Father } & Living & 73.8 & 59.3 & 66.5 & 49.7 & 97.2 & 96.7 & 90.0 & 88.1 & & & & \\
\hline & Died & 26.2 & 40.7 & 33.5 & 50.3 & 2.8 & 3.3 & 10.0 & 11.9 & & & & \\
\hline \multirow{2}{*}{ Poverty } & Poor & 46.3 & 47.3 & 40.1 & 37.8 & 7.0 & 5.4 & 18.8 & 14.3 & 60.3 & 54.5 & 63.2 & 66.3 \\
\hline & Non-poor & 53.7 & 52.7 & 59.9 & 62.2 & 93.0 & 94.6 & 81.2 & 85.7 & 39.7 & 45.5 & 36.8 & 33.7 \\
\hline
\end{tabular}

F: Female, M: Male

Further statistical analyses are shown on Tables 2, 3 and 4, with one exception that the analysis here is done on the whole dropout samples rather than age groups. This is duly because no substantial differences were found for each age group separately.

When area was compared with the reasons of not attendance, Table 2 was produced. In HBS 2005-2006, 37.8\% and $23.1 \%$ of the surveyed households were not interested to enroll their children in both areas. However, these figures have changed dramatically in the subsequent surveys more specifically in CLS 2010. The same story is clear with the child's attitude to enroll. It is important to notice that the schooling circumstances (No schools, Hard to reach schools, No female teachers) in the rural areas are much worse than urban areas. This result suggests a fair revision to the schooling distribution in Yemen through a strategic plan. Too young is a weird reason for not attending specially in both CLS 2010 and HBS 2014. It is also unexpected to find the percentage of "Too young" reason in urban areas to exceed the percentage of the rural areas.

Table 2. Area by reasons of not attending schools for the age group 6-17 years.

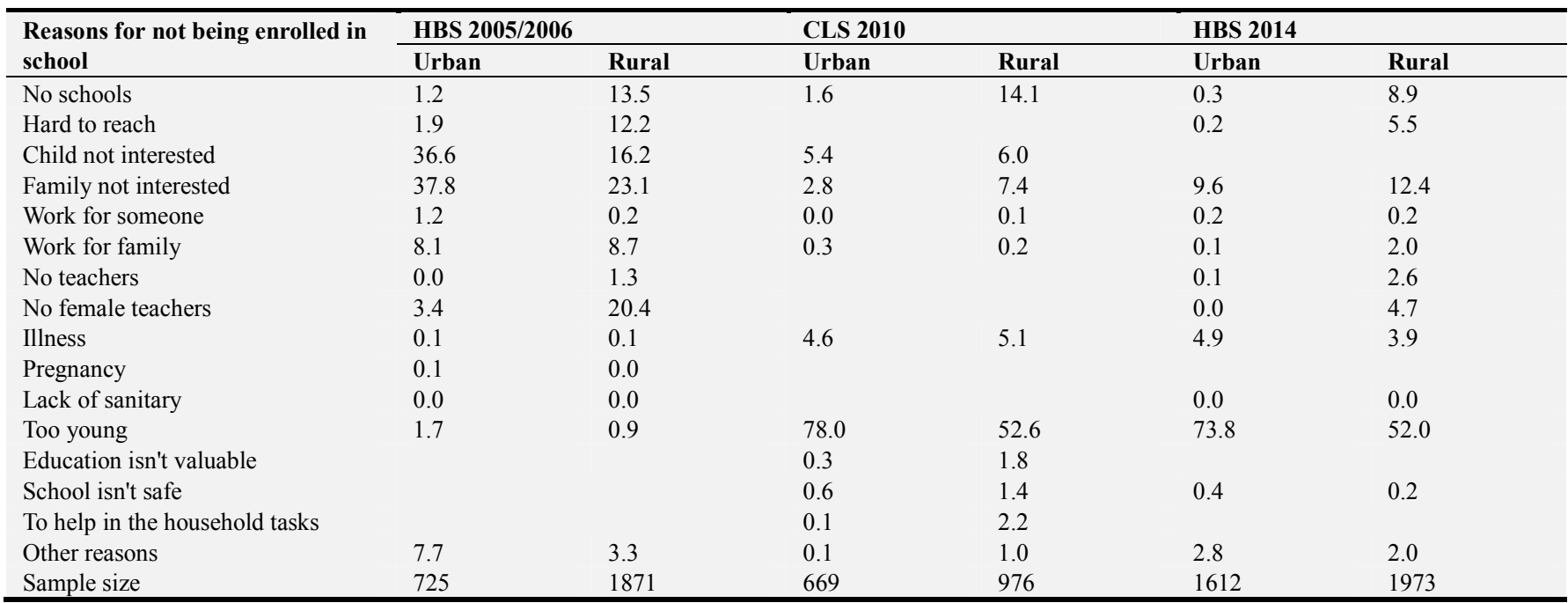

As shown on Table 1, HBS 2005-2006, CLS 2010 and HBS 2014 have included data on poverty. So, Table 3, compares the poverty status of households with the reasons that holding back their children from attending schools. Three factors take the lead as main reasons for not attending. These factors are family not interested, child not interested and no female teachers respectively for the HBS 2005-2006. Too young factor in the HBS 2014 seems unrealistic and hiding something inexpressible by households (HHs). In HBS 2005-2006, the percentage of poor children and adolescents (by virtue, households) was less than the rich. This percentage was reversed in HBS 2014 where the poor has increased by about 10 percent. In general, this table shows that poor children and adolescents are more vulnerable to be out of school than the rich. 
Table 3. Poverty by reasons of not attending school for the age group 6-17 years.

\begin{tabular}{|c|c|c|c|c|c|c|}
\hline \multirow{2}{*}{$\begin{array}{l}\text { Reasons for not being enrolled in } \\
\text { school }\end{array}$} & \multicolumn{2}{|c|}{ HBS 2005-2006 } & \multicolumn{2}{|l|}{ CLS 2010} & \multicolumn{2}{|l|}{ HBS 2014} \\
\hline & Non-poor & Poor & Non-poor & Poor & Non-poor & Poor \\
\hline No schools & 9.8 & 10.4 & 9.6 & 0.0 & 2.0 & 8.0 \\
\hline Hard to reach & 7.7 & 11.2 & & & 2.1 & 4.3 \\
\hline Child not interested & 24.3 & 19.2 & 6.1 & 0.0 & & \\
\hline Family not interested & 27.2 & 27.2 & 5.9 & 0.0 & 9.7 & 13.6 \\
\hline Work for someone & 0.4 & 0.6 & 0.1 & 0.0 & 0.1 & 0.3 \\
\hline Work for family & 9.3 & 7.7 & 0.3 & 0.0 & 1.0 & 1.4 \\
\hline No teachers & 0.9 & 1.0 & & & 0.1 & 2.6 \\
\hline No female teachers & 15.0 & 16.4 & & & 1.2 & 4.1 \\
\hline Illness & 0.1 & 0.1 & 5.2 & 0.0 & 5.0 & 4.4 \\
\hline Pregnancy & 0.1 & 0.0 & & & & \\
\hline Lack of sanitary & 0.0 & 0.0 & & & 0.0 & 0.0 \\
\hline Too young & 1.2 & 1.0 & 66.7 & 0.0 & 76.0 & 58.4 \\
\hline School isn't safe & & & 1.2 & 0.0 & 0.4 & 0.2 \\
\hline Education isn't valuable & & & 1.3 & 0.0 & & \\
\hline To help in the household tasks & & & 1.4 & 0.0 & & \\
\hline Other reasons & 3.8 & 5.4 & 0.7 & 0.0 & 2.4 & 2.7 \\
\hline Sample size & 1382 & 1214 & 1552 & 118 & 1469 & 1898 \\
\hline$\%$ & 53.2 & 46.8 & 92.9 & 7.1 & 43.6 & 56.4 \\
\hline
\end{tabular}

Finally, when area was compared with the poverty status of the dropouts, it was found that the poor are more concentrated on the rural than urban areas (Table 4). Again, this result gives an indication of the deep gap between urban and rural areas in Yemen in education attainments.

Table 4. Area by poverty.

\begin{tabular}{llllll}
\hline \multirow{2}{*}{ Poverty } & HBS 2005-2006 & & CLS 2010 & & HBS 2014 \\
\cline { 2 - 6 } & Urban & Rural & Urban & Rural & Urban \\
\hline Non-poor & 40.8 & 59.2 & 41.3 & 58.7 & 62.5 \\
Poor & 25.2 & 74.8 & 33.9 & 66.1 & 37.5 \\
Total & 1320 & 2557 & 681 & 989 & 32.5 \\
\hline
\end{tabular}

When the dependent variable is binary and the independent variables are categorical, the logistic regression model is appropriate method to study the relationship among the variables. Data analysis was done by logistic regression to assess the effect of each variable on the enrollment status through Backward Stepwise (Wald) method using SPSS 21.

The logistic regression model describes the relationship between a dichotomous response variable $\mathrm{Y}$, coded to take the values 1 or 0 for success and failure, respectively, i.e.

$$
\mathrm{P}(\mathrm{x})=\mathrm{y}=1 /\left[1+\exp \left(-\beta_{0}-\beta_{1} \mathrm{x}\right)\right]
$$

where $\mathrm{p}(\mathrm{x})$ denotes the probability of success when the explanatory variable has the value $\mathrm{x}$.

The two parameters $\beta_{0}$ and $\beta_{1}$ determine the location, slope and spread of the curve. And

$$
\begin{gathered}
\operatorname{Logit}(\mathrm{y})=\log [\mathrm{y} /(1-\mathrm{y})] \\
\operatorname{Logit}(\mathrm{P}(\mathrm{x}))=\log [\mathrm{P}(\mathrm{x}) /(1-\mathrm{P}(\mathrm{x}))]=\beta_{0}-\beta_{1} \mathrm{x}
\end{gathered}
$$

The ratio $\mathrm{P}(\mathrm{x}) /(1-\mathrm{P}(\mathrm{x}))$ in the above equation is the ratio between the probability of success and the probability of failure. That is, it is the odds of success! Hence, $\operatorname{Logit}(\mathrm{P}(\mathrm{x}))$ is the logarithm of the odds of success-called the log odds of success, given the value of $x$ the explanatory variable [25].

Again, two separate logistic regression analyses of the two age groups will be performed to study the relationship between enrollment and all factors listed on Table 1.

In HBS 2005-2006 except illness, pregnancy and lack of sanitation, all other factors are interacting significantly with school attendance (Table 5). In CLS 2010, six factors are associating significantly with school attendance among them illness, poverty and unwillingness of children to be enrolled. No female teachers, poverty, sex of child and area are the most important factors in the HBS 2014. Further, it can be seen that male children are still having more chance to be

\begin{tabular}{|c|c|c|c|c|c|c|}
\hline \multirow{2}{*}{ Age group 6-14 } & \multicolumn{2}{|c|}{ HBS 2005-2006 } & \multicolumn{2}{|c|}{ CLS 2010} & \multicolumn{2}{|c|}{ HBS 2014} \\
\hline & Sig. & $\operatorname{Exp}(B)$ & Sig. & $\operatorname{Exp}(B)$ & Sig. & $\operatorname{Exp}(B)$ \\
\hline No schools & 0.000 & 11.481 & - & - & - & - \\
\hline Hard to reach & 0.000 & 9.664 & & & - & - \\
\hline Child not interested & 0.000 & 2.265 & 0.030 & 4.828 & & \\
\hline Family not interested & 0.000 & 5.503 & - & - & - & - \\
\hline Work to someone & & & - & - & - & - \\
\hline Work for family & 0.000 & 3.195 & - & - & - & - \\
\hline
\end{tabular}
enrolled than female children.

Table 5. Logistic regression of reasons with out-of-school for age group 6-14 years. 


\begin{tabular}{|c|c|c|c|c|c|c|}
\hline \multirow{2}{*}{ Age group 6-14 } & \multicolumn{2}{|c|}{ HBS 2005-2006 } & \multicolumn{2}{|c|}{ CLS 2010} & \multicolumn{2}{|c|}{ HBS 2014} \\
\hline & Sig. & $\operatorname{Exp}(B)$ & Sig. & $\operatorname{Exp}(B)$ & Sig. & $\operatorname{Exp}(B)$ \\
\hline No teachers & 0.003 & 3.237 & & & - & - \\
\hline No female teachers & 0.000 & 2.164 & & & 0.000 & 171.269 \\
\hline Illness & - & - & 0.037 & 8.355 & - & - \\
\hline Pregnancy & - & - & & & & \\
\hline Lack of sanitation & - & - & & & & \\
\hline Too young & 0.000 & 11.126 & - & - & - & - \\
\hline Education isn't valuable & & & 0.000 & 0.004 & & \\
\hline School isn't safe & & & - & - & - & - \\
\hline To help in the household tasks & & & - & - & & \\
\hline $\operatorname{Sex}($ male $)$ & 0.000 & 0.266 & 0.026 & 1.475 & 0.000 & 0.766 \\
\hline Area (rural) & 0.000 & 1.985 & - & - & 0.000 & 1.415 \\
\hline Mother (died) & 0.000 & 6.045 & - & - & & \\
\hline Father (died) & 0.000 & 2.928 & 0.000 & 0.240 & & \\
\hline Poverty (poor) & 0.000 & 1.384 & 0.010 & 6.422 & 0.000 & 1.651 \\
\hline Other reasons & 0.000 & 7.690 & - & - & - & - \\
\hline Constant & 0.000 & 0.298 & 0.000 & 7.839 & 0.000 & 0.175 \\
\hline
\end{tabular}

Not significant

For the age group 15-17, no schools and hard to reach the available schools still important reasons in HBS 2005-2006 for not attending (Table 6). Promoting children and families to understand the crucial importance of education seems a top priority for decision makers. The analysis showed three main factors to be common in the three surveys; sex in favor of male children, area in favor of urban areas and poverty. It should be noted that in the presence of other reasons, no specific meaning for the constant in the regression analyses.

Table 6. Logistic regression of reasons of out-of-school for age group 15-17 years.

\begin{tabular}{|c|c|c|c|c|c|c|}
\hline \multirow{2}{*}{ Age group 15-17 } & \multicolumn{2}{|c|}{ HBS 2005-2006 } & \multicolumn{2}{|c|}{ CLS 2010} & \multicolumn{2}{|c|}{ HBS 2014} \\
\hline & Sig. & $\operatorname{Exp}(B)$ & Sig. & $\operatorname{Exp}(B)$ & Sig. & $\operatorname{Exp}(B)$ \\
\hline No schools & 0.000 & 6.540 & - & - & - & - \\
\hline Hard to reach & 0.000 & 4.051 & & & - & - \\
\hline Child not interested & 0.000 & 1.496 & 0.000 & 54.291 & & \\
\hline Family not interested & 0.000 & 2.414 & - & - & 0.000 & 27.775 \\
\hline Work to someone & 0.001 & 1.611 & - & - & - & - \\
\hline Work for family & - & - & - & - & - & - \\
\hline No female teachers & 0.000 & 2.318 & & & - & - \\
\hline Illness & - & - & 0.000 & 52.757 & - & - \\
\hline Pregnancy & - & - & & & & \\
\hline Lack of sanitation & - & - & & & & \\
\hline Too young & - & - & - & - & & \\
\hline Education isn't valuable & & & 0.001 & 16.348 & & \\
\hline School isn't safe & & & 0.014 & 13.051 & - & - \\
\hline Area (rural) & 0.000 & 2.290 & 0.000 & 3.649 & 0.000 & 3.392 \\
\hline Mother (died) & 0.000 & 5.879 & - & - & & \\
\hline Father (died) & 0.000 & 3.035 & - & - & & \\
\hline Poverty (poor) & 0.005 & 1.244 & 0.000 & 33.183 & 0.000 & 2.301 \\
\hline Other reasons & 0.000 & 2.321 & - & - & - & - \\
\hline Constant & 0.000 & 0.300 & 0.000 & 0.123 & 0.000 & 0.024 \\
\hline
\end{tabular}

Not significant

\section{Discussion}

Hunt (2008) stated "pupils' dropout reason does not consist of only one but several reasons" [11]. The case here seems no different but the hard part is to understand how the reasons are connected. In other words, no matter how many reasons but how one or several reasons strongly impacting and stimulating the dropout problem.

Looking at the reasons used in the three surveys and the refined reasons emerged by the logistic regression analysis, it is easy to distribute these reasons into four main categories; school related reasons, family-related reasons, work-related reasons and situation related reasons. The first three categories were discussed before $[12,13,26]$, but in the Yemen context, situation is so harsh more specifically in the rural areas. This harsh situation made it difficult to build and establish enough schools in all regions that made thousands of students unable to reach the available ones.

In this study, it is dealt only with children and adolescents who are not attending schools at the time of surveys. In other 
meaning, no idea whether the investigated children and adolescents had some schooling years in the past or not. Therefore, the present research is focusing on studying the present situation away from any other probable factors that may influence the dropout process.

In some countries, reasons of pupils' dropout are including overcrowded classrooms, the amount of schooling hours, pedagogical, missed too many school days, poor grades/failing, did not like school and could not keep up with school work and didactic skills [11, 13, 27, 28], in Yemenunfortunately- the problem still in providing schools and teachers in the first place. Building more schools and providing transportation or offering some kind of compensation for those who live far away from schools, should be a priority at the educational planners to tackle the problem of school absence and reaching schools. When there is no schools or teachers, children and adolescents are automatically out of education. However, no female teachers are another issue as it is an indication that in some areas norms are still prohibiting female students to be educated by male teachers. This problem is central in the female education context in Yemen and lots of efforts and patience should be devoted to break these old norms before moving forward. A suggested solution to tackle this problem is to give distinctive financial assistances and incentives to female teachers to settle down in the rural areas.

Four major factors were determined by Cook and Ezenne (2010) that influencing students' absenteeism in primary schools in Jamaica [29]. These factors are parental, student, community and school related issues. Each factor was further divided into subfactors. These subfactors are including financial constraints (poverty) of parents, sickness of students and poor transportation to schools. Attendance is a particular concern for low-income students, as they may have more barriers to attending schools and research on attendance across the U.S. indicates that higher rates of absenteeism are associated with higher levels of poverty [10]. Furthermore, other studies considered poverty as the main reason of students' absenteeism [30-32].

The associations between poverty, willingness to education and health are overlapping. For instance, if the family is poor, there is a greater risk that its members will get ill. Likewise, in the case of illness, the household economy will be affected negatively by medical costs and absence from work. The act of dropping out is influenced by an array of factors related to both the individual student and to the family, school and community-settings in which the students live. In line with other studies [33, 34], this study has proved a significant association between illness and school attendance. In fact, illness could affect the schooling of children and adolescents either directly by long-and-short-term absence or in their achievement. In line with many scholars, it is believed that dropout of schools is only the final stage of dynamic and cumulative process that is influenced by a variety of proximal and distal factors [15-17, 35]. Moreover, illness could lead to parents' mortality (orphanhood) and this could lead children or adolescents to stop education and work for someone (males) or work for the family (males + females) or to help in the household tasks (females). Orphanhood could also lead families or children to be not interested in education.

\section{Conclusion and Recommendations}

Looking at the data analysis results from the three surveys, leads -broadly- to consider six main dimensions affecting the school attendance in Yemen. These dimensions are poverty status of HHs, schools' situation, education interest (willingness), orphanhood, sex of children and adolescent and residence area. Each dimension constitutes some factors as in Table 7.

Table 7. The main dimensions affecting the school attendance in Yemen.

\begin{tabular}{|c|c|c|c|c|c|}
\hline Poverty & Schools situation & Willingness & Orphanhood & Sex child & Area \\
\hline Work for someone & No schools & Child not interested & Mother died & Male & Urban \\
\hline Work for family & Hard to reach & Family not interested & Father died & Female & Rural \\
\hline Illness & No teachers & Child is too young & & & \\
\hline \multirow[t]{2}{*}{ Help in the HH tasks } & No female teachers & Education isn't valuable & & & \\
\hline & School not safe & & & & \\
\hline
\end{tabular}

Accordingly, the following prototype or model is suggested (Figure 1), to address the dropout of schools' phenomenon in Yemen.

The prototype states that deep and long poverty situation at the HHs, leads definitely to both illness and loss of interest in education at the families and children. Illness could lead to children orphanhood and also to loss of interest in education either families or children. Orphanhood could lead children to work for someone (males), work for the family (males + females) and help in household tasks (females). Education interest can be negatively affected by non-availability of schools, teachers and female teachers. Moreover, factors such as the long distances to schools, safety of schools, the impression that education is not valuable and too young are also important in losing interest in education. Some of these factors are more likely to occur on the rural areas of Yemen.

So, any future planning to reduce the dropout in schools should take into consideration that alleviating poverty of the Yemeni people, improving the schooling distribution and conditions, stopping the war-to make schools safe- and increasing the awareness of the education importance, are together the only possible road map. 


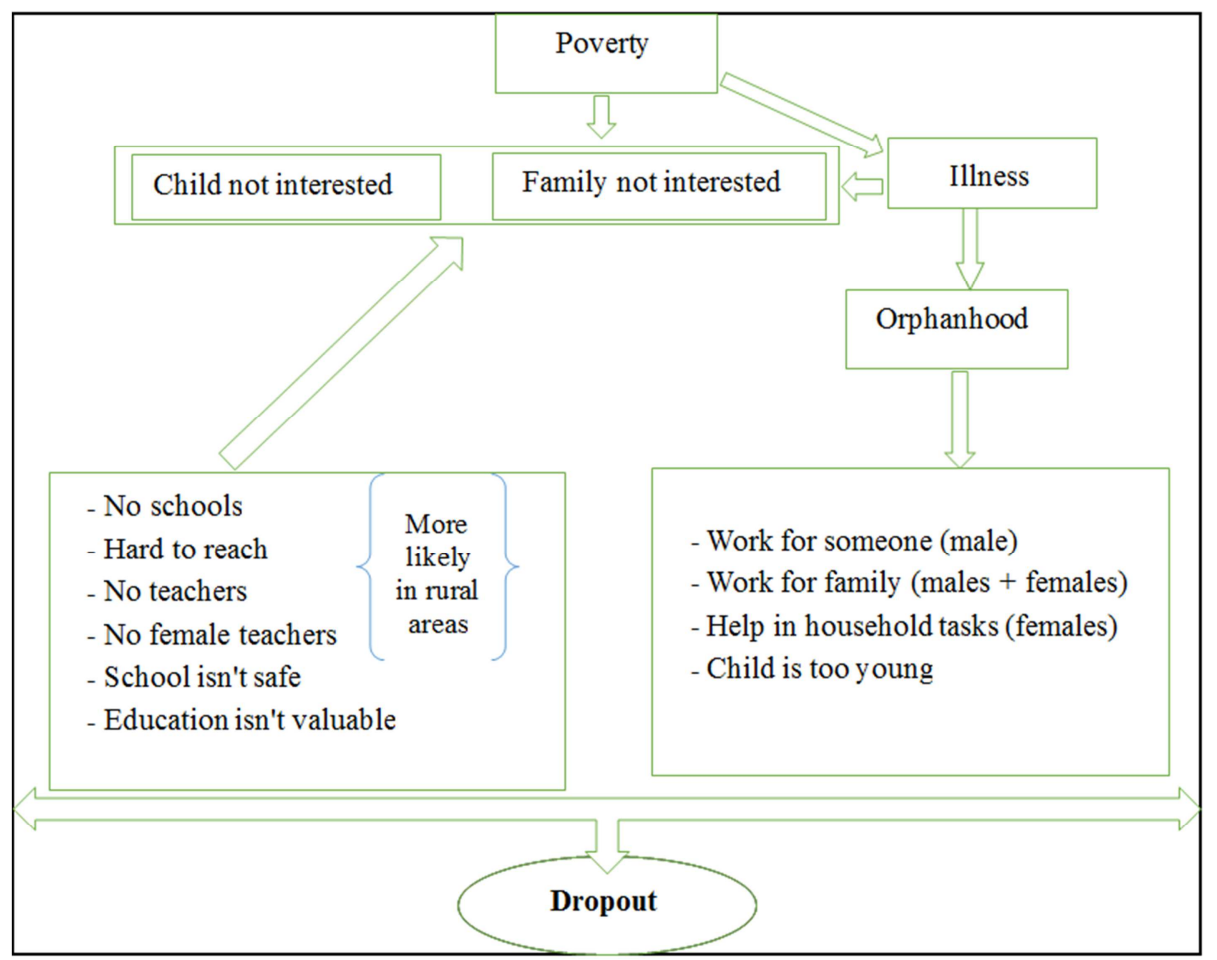

Figure 1. A suggested dropout model for Yemen.

\section{References}

[1] "Household Budget Survey Report (HBS) 2005/2006". Central Statistical Organization, Ministry of Planning and International Cooperation, Sana'a, Yemen.

[2] "Children Labor Survey Report (CLS) 2010". ILO, Yemen, 2012.

[3] "Household Budget Survey Report (HBS) 2014". Central Statistical Organization, Ministry of Planning and International Cooperation, Sana'a, Yemen.

[4] UNICEF. "Born into War 1000 Days of Lost Children; Yemen is one of the worst places in the world to be a child". \#ChildrenUnderAttack, January 2018.

[5] UNICEF. "If not in school, the paths children cross in Yemen". \#IfNotInSchool, March 2018.

[6] Central Statistical Organization (CSO). "Population Projections of Yemen 2005-2025". CSO, Yemen. 2018. http://www.cso-yemen.org/content.php?lng=arabic\&id=553.

[7] World Bank. "Education in the Middle East North Africa: a strategy towards learning for development". Washington, DC: World Bank. 1999.

[8] World Bank. "The Road not Traveled Education Reform in the MENA Region". Washington, DC: World Bank. 2007.

[9] UNICEF. "Yemen National Social Protection Monitoring Survey (NSPMS): 2012-2013 Final Report". International Policy Centre for Inclusive Growth, United Nations Development Programme and the United Nations Children's Fund. 2014. http://www.ipcundp.org/pub/eng/Yemen_National_Social_Protection_Monito ring_Survey_2012_2013.pdf.
[10] T. Spradlin, K. Cierniak, D. Shi, and M. Chen. "Attendance and Chronic Absenteeism in Indiana: The Impact on Student Achievement". Center for Evaluation \& Education Policy (CEEP), Education Policy Brief, 2012, 10(3): 1-12.

[11] F. Hunt. "Dropping out from school: A Cross Country Review of Literature". Research Monograph, No. 16. University of Sussex Centre for International Education. 2008.

[12] J. M. Bridgeland, J. J. Dilulio Jr., and K. B. Morison. "The silent epidemic: Perspectives on high school dropouts". Washington, D. C.: Civil Enterprises. 2006.

[13] S. Rotermund. "Why students drop out of high school: Comparisons from three national surveys". Santa Barbara: California Dropout Research Project, University of California, Santa Barbara. Retrieved October 7, 2008. http://lmri.ucsb.edu/dropouts/pubs.htm.

[14] R. W. Rumberger and A. L. Lim. "Why Students Drop out of School: A Review of 25 years of Research". California Dropout Research Project Report \#15, University of California, Santa Barbara. 2008.

[15] R. W. Rumberger. "High school dropouts: A review of issues and evidence". Review of Educational Research, 1987, 57: 101-121.

[16] G. G. Wehlage, R. A. Rutter, G. A. Smith, N. Lesko and R. R. Fernandez. "Reducing the risk: Schools as communities of support". New York: Falmer Press. 1989.

[17] J. D. Finn. "Withdrawing from school". Review of Educational Research, 1989, 59: 117-142.

[18] D. Card. "The Causal effect of Education on Earnings". Handbook of Labor Economics, Vol. 3, Part A, Amsterdam, Elsevier: 1999, Chapter 30:1801-1863. http://davidcard.berkeley.edu/papers/causal_educ_earnings.pd f. 
[19] D. M. Cutler and A. Lleras-Muney. "Education and Health: Evaluating Theories and Evidence". NBER Working Paper, No. 12352. Cambridge, MA, National Bureau of Economic Research. 2006.

[20] F. Ricci and M. Zachariadis. "Education Externalities on Longevity". Economica. 2012. doi: 10.1111/ecca. 2013.

[21] D. Filmer. "The Structure of Social Disparities in Education: Gender and Wealth". World Bank, Washington DC. 1999.

[22] S. A. El Dawla. "Traps for Democracy". Egypt National Report. The Social Watch. 2000.

[23] R. Assaad, L. Deborah and N. Zibani. "The Effect of Child Work on School Enrollment in Egypt". A paper presented at the Workshop on Poverty and its determinants in the Middle East, Sana'a, Yemen, 2001.

[24] S. Elkogali and S. El Daw. "Poverty, Human Capital and Gender: A Comparative Study of Yemen and Egypt". ERF, Working Papers 0123, Economic Research Forum, revised 08 Sep 2001 .

[25] J. Neter, M. H. Kutner, C. J. Nachtsheim and W. Wasserman. "Applied Linear Regression Models". $3^{\text {rd }}$ ed. Chicago, IL: Irwin. 1998.

[26] M. Kibria."The Magnitude of Cultural Factors That Affect School Enrolment and Retention in Afghanistan: An Analysis Through Hofstede's Model". Canadian Social Science, 2013, 9(6): 161-168.

[27] C. Colcough, P. Rose and M. Tembon. "Gender inequalities in primary schooling: The Roles of poverty and adverse cultural practice". International Journal of Educational Development, 2000, 20: 5-27.
[28] S. Ghumanand C. B. Lloyd. "Teacher Absence as a Factor in Gender Inequalities in Access to Primary Schooling in Rural Pakistan". Working Paper, No 1. New York: Population Council. 2007.

[29] L. Cook and A. Ezenne. "Factors Influencing Student's Absenteeism in Primary School in Jamaica, Perspectives of Community Members". Caribbean curriculum, 2010, 17: 33-57.

[30] C. A. Kearney. "School Absenteeism and School Refusal Behavior in youth: A contemporary review". ScienceDirect, 2008, 28: 451-471.

[31] S. Peterson. "Barriers to Accessing Primary Education in Conflicted Affected Fragile States". (Final Report). London: International Save the Children Alliance. 2009.

[32] M. Guptaand P. Lata."Absenteeism in Schools: A Chronic Problem in the Present Time". Educational Confab, 2014, 3(1): $11-16$

[33] M. Batbaatar, T. Bold, J. Marshall, D. Oyuntsetseg, C. Tamir and G. Tumennast. "Children on the move: rural-urban migration and access to education in Mongolia". CHIP Report No. 17, Save the Children UK/CHIP. 2006.

[34] P. Pridmore. "Impact of Health on Education Access and Achievement: A Cross-National Review of the Research Evidence". UK: University of Sussex. 2007.

[35] F. M. Newmann. "Student engagement and achievement in American secondary schools". New York: Teachers College Press. 1992. 